\title{
Diffusion of green power products in Switzerland
}

\author{
Rolf Wüstenhagen ${ }^{\mathrm{a}, *}$, Jochen Markard ${ }^{\mathrm{b}}$, Bernhard Truffer ${ }^{\mathrm{b}}$ \\ ${ }^{a}$ Institute for Economy and the Environment, University of St. Gallen (IWOe-HSG), Tigerbergstrasse 2, CH-9000 St. Gallen, Switzerland \\ ${ }^{\mathrm{b}}$ Swiss Federal Institute for Environmental Science and Technology (EAWAG), CH-6047 Kastanienbaum, Switzerland
}

\begin{abstract}
As in many other European countries, green electricity is an emerging product in Switzerland as well. Although the market is yet to be liberalised, more than 100 of the 1200 Swiss electric utilities offer some sort of green electricity product to their customers. Successful companies like the municipal utilities of the cities of Zurich and Berne have reached customer response rates of up to $4 \%$, while still maintaining cost-based pricing, i.e. charging their customers price premiums of $400-700 \%$ per $\mathrm{kWh}$. While most of the products still rely on mainly photovoltaics, some utilities have started to introduce mixed green electricity products also including wind power. With a share of $60 \%$ in the Swiss generation mix, hydropower's role in the green electricity mix was also an issue to emerge causing controversial debate. While being renewable, hydropower is not considered environmentally benign by all the stakeholders, and unlike new renewables (solar, wind, biomass), there is little room for new hydropower generation facilities in Switzerland. The green electricity labelling scheme "Naturemade" tackles that issue. The labelling organisation has evolved from a process with broad stakeholder involvement, which included environmental NGOs, scientific institutions, green electricity providers, renewable energy advocates, government bodies and consumer organisations. The analysis in this paper is based on a diffusion theory framework. It identifies and characterises different phases of (past and future) market development, and stresses the importance of eco-labelling as a tool to facilitate the transition from niche to mass market. Finally, we also discuss conclusions that can be drawn from the Swiss case towards market development and labelling on a European level.
\end{abstract}

(C) 2002 Elsevier Science Ltd. All rights reserved.

\section{Introduction}

Switzerland has a population of about 7.1 million people. Electricity accounts for $22 \%$ of Swiss final energy consumption, with a specific electricity consumption of $7.380 \mathrm{kWh}$ per capita in 2000 (BfE, 2001a). This per capita consumption is slightly above the EU average of $6.063 \mathrm{kWh}$, and well below three of the Scandinavian countries. ${ }^{1}$ The Swiss electricity system is mainly based on hydro and nuclear power generation. Annual production in 2000 was $65 \mathrm{TWh}$, domestic consumption $56 \mathrm{TWh}$ (BfE, 2001b), i.e. the country is a net exporter of electricity. Due to its central geographical location on the borders of France, Italy, Germany and Austria, Switzerland has traditionally been strongly involved in international electricity trading. Cross-border trades amount to about $1 / 3$ of total domestic generation $(20 \mathrm{TWh})$, typically with net exports in summer and

\footnotetext{
*Corresponding author. Tel.: +41-76-306-43-13.

E-mail addresses: rolf.wuestenhagen@unisg.ch (R. Wüstenhagen), markard@eawag.ch (J. Markard), truffer@eawag.ch (B. Truffer).

${ }^{1}$ Norway, Sweden and Finland.
}

slight net imports in winter. Fig. 1 shows the annual growth of electricity consumption in Switzerland during the 1990s. On average, consumption has grown by only $1.2 \%$ annually, reflecting de facto stagnation in GDP throughout the 1990s. Towards the end of the decade, annual growth rates had risen to $2.0 \%(1997 / 98)$ and $3.2 \%(1998 / 99)$, respectively, but then flattened out again with $2.3 \%$ for $1999 / 2000$.

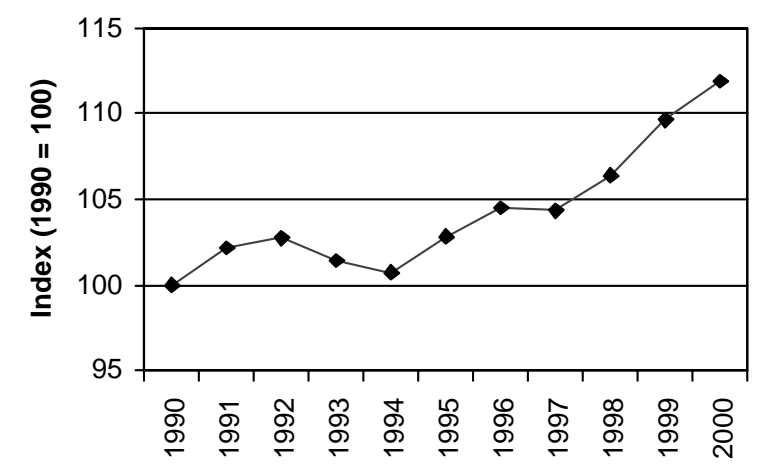

Fig. 1. Growth in Swiss electricity consumption 1990-2000 (Source: BfE, 2001b). 
Hydropower accounts for $58 \%$ of power generation, another $38 \%$ are nuclear and about $3 \%$ of the electricity is generated from fossil fuels (BfE, 2001b). New renewable energy sources like solar power, wind or biomass play a marginal role in electricity supply, contributing only $0.031 \mathrm{TWh}$ or $0.05 \%$. Electricity from waste incineration, landfill gas and wastewater purification contributes another $0.82 \mathrm{TWh}$ (BfE, 2001c).

As for the industry structure, there are about 1200 electric utilities, many of them small to very small municipal or local utilities. Many of the small utilities are only distributors, while some of the larger utilities are vertically integrated from generation through transmission to distribution. The high voltage grid is until now owned by the 6 major utilities (Ueberlandwerke), but the new electricity market act requires the creation of a national grid company within the next 3 years (EMG, 2000).

Compared to many other European countries, Switzerland is lagging behind in the process of electricity market liberalisation. Switzerland is not a member of the European Union, hence it does not automatically apply EU legislation. A draft Swiss Electricity Market Act (EMG) had been presented by the federal government in February 1998. After vivid debates, mainly on the issues of stranded investments and the competitiveness of hydropower, federal parliament accepted a final version in December 2000. This includes a liberalisation process in stages, starting with large consumers $(>20 \mathrm{GWh})$ and reaching the household level after 6 years. It also suggests that green electricity could be sold to any consumer from day one. Before this law will be enacted, there will be a referendum, now scheduled for September 2002.

One of the reasons for the delay in the commencement of the act has been a referendum about energy taxes, which took place on September 24, 2000 (Jegen and Wüstenhagen, 2001). People had to vote on three proposals: a popular initiative on solar energy (SolarInitiative) and two government proposals, namely for the promotion of renewable energies (Förderabgabe) and a constitutional article to introduce an eco-tax (Umweltabgabe). All three had in common that they would have raised a tax on non-renewable energies. The differences were in the level of the tax $(0.3 \mathrm{Rp}$. $/ \mathrm{kWh}$ for the Förderabgabe, $0.5 \mathrm{Rp}$./kWh for the Solar-Initiative, and up to $2.0 \mathrm{Rp}$./kWh for the Umweltabgabe), ${ }^{2}$ and in the appropriation of the funds for different uses, namely the promotion of renewable energies and energy efficiency (Solar-Initiative and Förderabgabe) vs. the reduction of labour costs (Umweltabgabe). Compared to other countries, the proposed levels of taxation were rather low, but still there was substantial opposition

\footnotetext{
${ }^{2}$ This corresponds to $0.20,0.34$, and 1.36 Euro-Cents $/ \mathrm{kWh}$, for Förderabgabe, Solar-Initiative and Umweltabgabe, respectively.
}

from industrial associations who campaigned against all three proposals. The coincidence with price spikes in the oil market in summer 2000 finally led to a rejection of all proposals in the popular vote. While the results were rather tight in the case of the two government proposals $(46.6 \%$ "yes" vs. $53.4 \%$ "no" to the Förderabgabe, and $44.6 \%$ vs. $55.4 \%$ to the Umweltabgabe), the popular initiative for the promotion of solar energy was rejected by two thirds of the voters. ${ }^{3}$ An analysis of the results showed that people living in cities, with higher education, and with social democratic political orientation were in favour of the proposals, while they were opposed in rural areas and among voters with lower education or right-wing orientation (GfS, 2000). Looking at regional differences, it is striking that only three out of 26 cantons voted in favour of the ecological tax reform proposal (Umweltabgabe). Those were Basel-Stadt, which has already introduced energy taxes on the cantonal level; Zurich, where the municipal utility has the largest share of solar power customers in the country; and Graubünden, where the majority of hydropower is generated.

In the next section, we will describe subsequent phases of green power market development in Switzerland following a diffusion theory perspective. The analysis will show that quality assurance and credibility of claims are key factors for the transition from early niche markets into a broader mass market. Therefore, in Section 3, we will analyse the development of a broadly accepted green power labelling scheme in Switzerland, and discuss the particular role of hydropower. In the concluding section, we will summarise the developments in Switzerland and draw conclusions for the European market.

\section{Phases of green power market development in Switzerland}

The development of the green power market in Switzerland ${ }^{4}$ can be interpreted in terms of the diffusion of a product innovation. As Rogers (1995) has shown, the diffusion of innovations in social systems can be described as following a sigmoid curve. Villiger et al. (2000) have extended this analysis to describe the market penetration of green product innovations in the food, clothing and electricity sectors (see Fig. 2). ${ }^{5}$

\footnotetext{
${ }^{3}$ For the results, cf. Neue Zürcher Zeitung, 25. September 2000, http://www.nzz.ch/dossiers/dossiers2000/abstimmung0924/

${ }^{4}$ Unless indicated otherwise, information in this section is mainly based on Wüstenhagen (2000).

${ }^{5}$ See also Holt and Wiser (1999) for an application of the diffusion curve to green power demand in the US, and Nordmann (1997) for a combined model of diffusion on the customer and supplier sides of the PV market.
} 


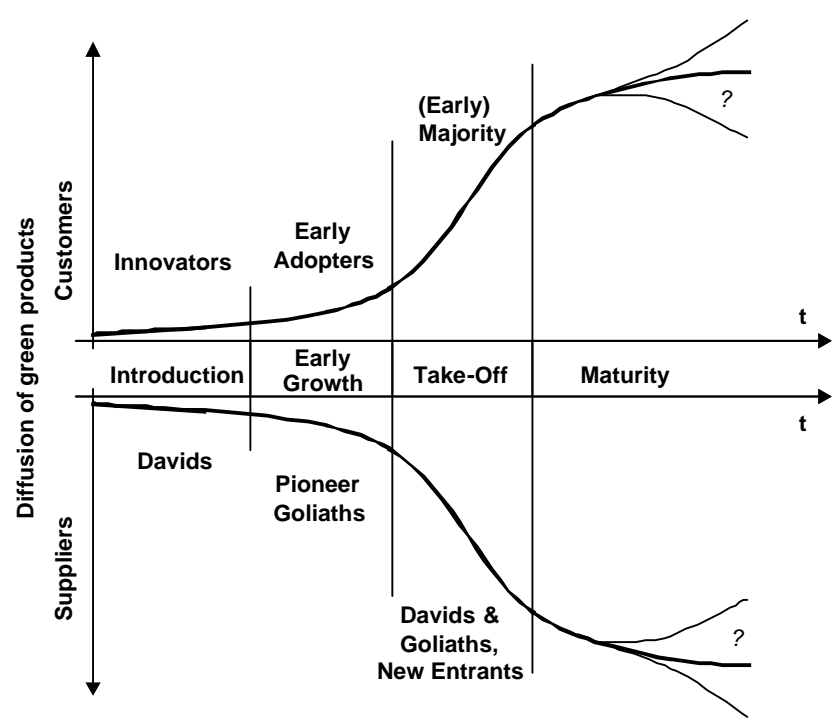

Fig. 2. Diffusion of green products over time among customers and suppliers (Source: Villiger et al., 2000, p. 32).

Following their terminology, the development of the green market can be divided into four phases: introduction, early growth, take-off, and maturity. While the main indicator of these phases is the increasing market share of green products over time, they can also be distinguished by

- the types of customers that choose the products (from innovators through early adopters, early and late majority to laggards),

- the types of suppliers that sell green products (from Davids through Pioneer Goliaths to a mix of Davids, Goliaths, and New Entrants), and finally

- the types of products dominating the green market (from high-end environmental products through a broader range of environmental qualities to standardised, labelled products for the mass market).

The development of the Swiss green power market shall be described along these lines, analysing the major suppliers, customers, market share, prevailing products and degree of market liberalisation in each phase. It will be argued that the Swiss green power market is now in the transition phase from early growth to take-off. This means that applying the general concept of the diffusion curve includes not only "hard facts" about historical developments, but includes some hypotheses about the future development of the market. This transition point and the inherent uncertainty about the future should be kept in mind when interpreting our analysis.

\subsection{Introduction phase (late 1980s to early 1990s)}

The cradle of the Swiss green power market is located in the late 1980s/early 1990s. In this introduction phase, the main actors were committed private persons-like technology enthusiasts or environmentally conscious homeowners - as well as grassroots movements like the "Appenzellische Vereinigung zur Förderung umweltfreundlicher Energien" (Association for the promotion of renewable energies in the canton of Appenzell, founded in 1991), who started experimenting with the use of solar energy. Some early pioneers among the electric utilities, like Elektra Birseck Münchenstein $(\mathrm{EBM}),{ }^{6}$ joined them in their efforts by promoting voluntary contributions of household customers to the establishment of new PV generation facilities within their programme "Sonnenstrom für jedermann" (Solar electricity for everyone). Other utilities, like Industrielle Betriebe Burgdorf, ${ }^{7}$ chose to use a feed-in tariff for the promotion of renewables that was financed by a charge paid by all consumers. Besides these bottom-up initiatives of the smaller utilities, the industry's "Goliaths" did not pay much attention to the use of new renewables.

The typical green electricity customers in this phase were highly environmentally aware consumers with a strong interest in renewable energy, and readiness to take significant efforts to get to their products. The market share in this early phase was very modest, and market liberalisation was far from getting on the political agenda.

\subsection{Early growth (late 1990s)}

In the late 1990s, market liberalisation gained increasing attention in the political debate, and at the same time there was a significant expansion of the green power market in Switzerland. A number of committed municipal utilities, like Elektrizitätswerk der Stadt Zurich (EWZ, municipal utility of the City of Zurich), who have taken a more marketing-oriented approach to promoting green electricity, have been important actors on the supply side in this phase. There also was a joint effort to promote solar power products in a programme called "Solarstrom vom EW" (Solar power from your local utility), supported by the Federal Energy Agency and the Association of Swiss Electric Utilities (VSE). Until today, about 100 utilities have set up green power offerings within this programme, ${ }^{8}$ most of which are dominated by PV products, with prices per $\mathrm{kWh}$ that are 4-7 times higher than the price of ordinary electricity $(1.00-1.60 \mathrm{Fr} . / \mathrm{kWh}){ }^{9}$ This shows clearly that these products have - until now - not been designed to reach the mass market but rather to serve a small market niche

\footnotetext{
${ }^{6} \mathrm{http}: / /$ www.ebm.ch/

${ }^{7}$ http://www.burgdorf.ch/cgi/verwaltung/abteilungen/ind_elektrizitat.asp

${ }^{8}$ See http://www.strom.ch/deutsch/ch-strom/solarstrom-ew.asp for a list of suppliers.

${ }^{9} 0.68-1.08 € / \mathrm{kWh}$
} 
of price-insensitive, "dark green" consumers. Nevertheless, a considerable amount of consumers do buy solar power at these high prices. EWZ at Zurich alone sells solar electricity to 5500 customers and has installed 1.68 MW new PV generation capacity within the last 4 years through its green power marketing programme. Overall, about 25,000 households in Switzerland cover part of their electricity consumption by solar electricity provided from their local utility. ${ }^{10}$ It is estimated that the 1999 sales of solar electricity products in Switzerland were about 2000-2500 MWh/a (Linder, 1999). The share of participating households ranges from almost zero to $4.4 \%$, and the market share within the supply areas of utilities is still below $1 \%$ (Wüstenhagen, 1998). In addition to the high prices, the low market share can also be attributed to the low marketing (communication) intensity of most of the programmes and to the mere fact that they have been introduced only recently. For example, a survey among customers of 10 solar power providers in Switzerland showed that $70 \%$ of the customers had never heard about the green offering of their utility (Linder, 1999).

There are some examples, however, of more proactive and professional approaches to marketing, which can be seen as first signs of an upcoming take-off phase. Such examples include different aspects of the marketing mix, such as product design, pricing and communication. As for product design, some suppliers start to experiment with mixed green electricity products, including other (cheaper) forms of renewable energy like wind power (e.g. Elektrizitätswerk der Stadt Bern, EWB) or small hydro (e.g. Industrielle Betriebe Burgdorf, IBB). Regarding pricing, higher shares of other renewables and the inclusion of government subsidies in the case of PV leads to somewhat lower premiums. As for communication, EWZ has committed itself to event marketing. They offer organisers of popular events (like the annual Street Parade) to buy part of their electricity from photovoltaics, which in turn gives EWZ a good marketing platform for their solar power product. Another smart example is the partnership between Juvent SA, a windpower subsidiary of BKW Energie AG, with Fromagerie Spielhofer SA, a small producer of dairy products, who has launched a cheese branded "Eolienne" (wind cheese) - the brand being owned by the utility (Spielhofer, 2000).

It can be concluded that during the early growth phase, utilities have had some success in increasing the level of PV capacity in Switzerland, but the growth is still on a low level. Nevertheless, the early consumerdriven offerings did cause a significantly stronger growth than what had been achieved in previous years with direct public policy support. This can be illustrated

\footnotetext{
${ }^{10}$ See http://www.strom.ch/deutsch/ch-strom/solarstrom-news-solarstromangebot.asp
}

by the case of the city of Zurich, where a public support scheme led to little growth in the years 1992-1996, and where substantial progress followed the introduction of the solar power marketing campaign (cf. Fig. 3). ${ }^{11}$

As for the consumers that have bought green electricity in the early growth phase, there has been a shift from the renewable energy enthusiasts in the introduction phase to a wider range of environmentally aware citizens. There was some overlap to people buying organic food products in the supermarket (such as the Naturaplan launched by food retailer Coop in 1993), as opposed to the early niche customers of specialised whole food stores who accounted for most of the organic food sales in the early phase of market development. Clearly, given the high green power prices, these customers were still relatively price-insensitive. ${ }^{12}$ However, most product offerings included the option for a customer to buy just a small yearly amount of renewables, so the actual premium that people paid per month (typically $15-30 \mathrm{CHF} /$ month) was lower than the high premium per $\mathrm{kWh}$ suggests. As the majority of product offerings included local (solar) capacity development, local community orientation may have played a role among customers in that phase, too. Besides residential customers, some pioneering business customers entered the market as well, such as the detergent manufacturer Held AG who installed a solar PV power plant on the roof of the factory in cooperation with the local utility EW Steffisburg, who used the new capacity to set up a new solar power offering for residential customers in the region. Business customers in the early growth phase were typically smaller businesses whose owner had a strong environmental orientation (similar to the residential customers in the introduction phase).

\subsection{Take-off (early 2000s)}

The turn of the century has marked a change for the green power market in Switzerland, which raises expectations about growth in the coming years. We want to touch briefly upon three aspects of this beginning take-off phase: A growing interest among business customers (B2B, Business-to-Business Marketing), the emergence of competitive green electricity

\footnotetext{
${ }^{11}$ The column on the right indicated the political goal for PV capacity that had been set by the Swiss government within the programme "Energie 2000" in the early 1990s. It can be seen that the traditional public policy support before the introduction of the solar power marketing campaign has failed to come close to that goal by any means.

${ }^{12}$ In the terminology of Roper Starch Worldwide's "Green Gauge Report", those customers could be referred to as "Greenback Greens", i.e. they tend to be looking for market solutions to environmental problems and are willing to pay a relatively high premium to somebody who helps them reduce the environmental impact of their consumption (cf. Roper Starch Worldwide 2001).
} 


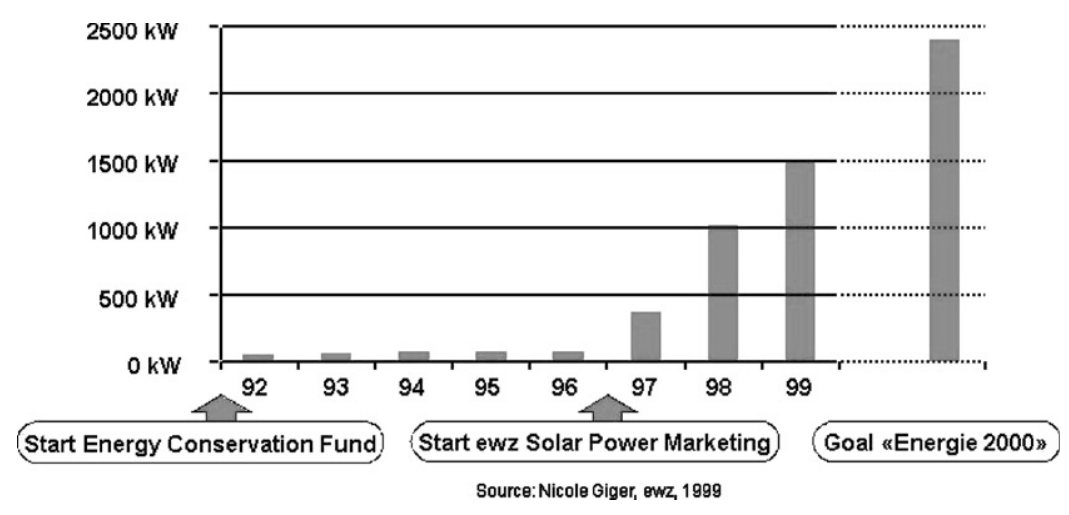

Fig. 3. PV capacity in the city of Zurich before and after launching the EWZ solar power marketing campaign (Source: Giger, 1999).

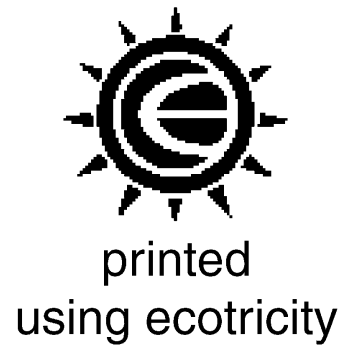

Fig. 4. Increasing the visibility of green power purchases is crucial in B2B marketing (Source: Ecotricity-The Renewable Energy Compnay, UK, http://www.ecotricity.co.uk)

products including hydropower, and the development of an eco-labelling and certification scheme.

Apart from a continuing move through the diffusion curve among private customers, green electricity starts to become an attractive option for business customers as well. Due to the higher consumption level of businesses, this may give a strong impetus to the green power market. The motivation for a business to buy green electricity can be threefold (Truffer, 1998; Wüstenhagen, 2000, pp. 135-139). One option may be for the company to improve its environmental performance by purchasing green power. This can be interesting if a company has introduced an Environmental Management System that implies a need for continuous improvement. An example is the former telecommunications monopolist Swisscom who purchases a share of its electricity from EWZ's solar power offering. Another option may be for business customers to use the green electricity purchase in their marketing mix as part of a differentiation strategy. The above-mentioned wind cheese is a prime example of this sort of motivation. For this option to be attractive for business customers, a green power supplier has to increase the visibility of the purchasing decision, for example by creating a brand or logo that can be used in the customer's marketing materials. Fig. 4 shows an example from the UK: The Renewable Energy Company provides the customers of its "Ecotricity" product (in this case a printing company) with a logo that they can use in their marketing materials.

A third option is that the business customer buys green electricity as part of a defensive strategy to safeguard against critical stakeholders from the environmental community. The green power purchases of customers like Zurich Airport or its Los Angeles counterpart as well as Toyota Motor Company in the US can probably be assigned to this category.

Another indication of an upcoming take-off phase is the emergence of competitive ${ }^{13}$ green power products, as opposed to the offerings of monopolists in the early growth phase. A prime example of such a product has been the launch of "Pure Power St. Moritz" by Rätia Energie AG in April 2000, ${ }^{14}$ as well as the announcement of Kraftwerke Oberhasli (KWO) that they intend to market their hydropower under the brand "Grimselstrom" that indicates the geographical area of origin. ${ }^{15}$ These are interesting examples of a convergence of marketing for tourist destinations and green electricity. The fact that these branding strategies have been announced while the legislator intends to wait for another 6 years to full market liberalisation reflects the international orientation of the Swiss power suppliers, who also try to market their electricity on the liberalised markets in the neighbouring countries, mainly Germany and Italy. The examples mentioned here also show another tendency in green power marketing which is that the previous focus on pure solar (or pure new renewable) products is shifting towards an inclusion of (existing, large) hydropower. Such an inclusion provides both opportunities (in terms of lower costs and high availability) and threats for the development of the green power market (in terms of a low credibility of

\footnotetext{
${ }^{13}$ By competitive products we mean products that are aimed at customers on a liberalised market and are designed to give the electricity retailer a competitive advantage. It is of course difficult to distinguish competitive and non-competitive offerings in the transition phase.

${ }^{14} \mathrm{http}: / /$ www.repower.ch/

${ }^{15}$ http://www.kwo.ch/
} 
products from existing plants - the "old vine in new bottles" issue). Possible responses would be minimum requirements for new renewables content in green products or additional criteria that restrict the inclusion of hydropower to environmentally benign facilities. Both issues have been discussed in the development of a green electricity labelling scheme in Switzerland (cf. Section 3). A credible and widely accepted eco-labelling scheme is important to secure a smooth transition of the market as it grows from the enthusiastic niche consumers and suppliers to the wide field of the mainstream market. To date, about $5.7 \%$ of the total Swiss electricity generation (3.7 TWh) have been certified according to the Swiss labelling scheme Naturemade (Naturemade, 2001). This includes $7.5 \mathrm{GWh}$ of new renewables (solar, wind and biomass), and $140 \mathrm{GWh}$ of low impact hydropower (Naturemade star certified).

\subsection{Maturity (2005 ff.)}

It is too early to predict how the green power market is going to develop after passing today's take-off phase. Compared to countries that are further down the liberalisation road like Germany or the US states of Pennsylvania and Texas, very different scenarios seem possible. In a pessimistic view, inspired to some extent by the current market development in Germany, the Swiss green power market might split up into a large segment that is covered by plain hydropower with no environmental value added, and a small premium segment of new renewable products, that is heavily dependent on public policy support. In Germany, the government subsidies for solar, wind and biomass have had much stronger impact on new renewable energy capacity than green electricity marketing strategies. However, with the rejection of the energy taxation proposals in the popular vote of September 2000, this strong reliance on public policy support is not a viable way forward in Switzerland, so the development in some US states may rather be a transferable example. Given the particular Swiss electricity generation mix, we think that a rational way of dealing with hydropower is key to such a market-driven development that forms the base of our optimistic scenario. If the majority of suppliers recognises the need to provide products that are at the same time cost-competitive (i.e. in the range of $10-30 \%$ price premium rather than today's $400-700 \%$ ) and provide a clear added value in terms of environmental improvements and/or new renewable generation capacity, then we estimate that this might result in a market share of (mixed) green electricity products in the 20 $30 \%$ range. This would also give substantial impetus to the development of the market for new renewable energies. Again, labelling is a crucial factor to bring this about, because it provides guidance both to the product designer and to the consumer.
The following table summarises the four phases of green electricity market development in Switzerland. It reflects the changing importance of different types of suppliers and consumers. It also illustrates the coevolution of diffusion and product development, ranging from the early distributed PV offerings in the introduction phase through a range of green electricity blends also encompassing some hydropower in the early growth phase to more standardised, certified green electricity products in the take-off and maturity phases (Fig. 5). ${ }^{16}$

\section{The development of a Swiss eco-label for electricity}

As we have discussed in Section 2, the Swiss green electricity market has left its early stages behind and is now about to make the transition from niche to mass market. This means changes on the supplier side, on the customer side and in terms of the products that are being offered. An important tool that gives mass market customers as well as suppliers and their product design guidance in making the transition from niche to mass market is an eco-labelling scheme for green electricity. ${ }^{17}$ In what we described as the early growth phase, a diverse group of stakeholders recognised and addressed this challenge. They created an independent organisation named Verein für umweltgerechte Elektrizität (VUE-Association for Environmentally Sound Electricity) in summer 2000, which then launched the label "Naturemade". The following section analyses in some detail the criteria and function of the Swiss label (3.1), the process of its development as a way of cooperative environmental problem solving (3.2), and possible implications for ongoing efforts to introduce a harmonised European green electricity label (3.3).

\subsection{Naturemade - the Swiss labelling scheme}

The Swiss green electricity labelling scheme ${ }^{18}$ aims at promoting renewable energy, giving incentives for new renewable energy development (PV, wind, biomass) and for environmental improvements of existing hydropower plants (Brandes, 2001). It has taken a two-level approach: Level one, Naturemade basic, applies to all electricity from renewable sources, including all existing hydropower plants. Level two, Naturemade star, applies to new renewable energies like solar, wind, biomass, as

\footnotetext{
${ }^{16}$ Sources for data: introduction, early growth and take-off phases: see references in the text above. Maturity phase: authors' own estimates. Italic indicates that these are assumptions about future market development.

${ }^{17} \mathrm{cf}$. Truffer et al., 2001a for more background on this argument.

${ }^{18}$ For a more detailed description of the principles and criteria of Naturemade cf. Kiefer, 2000 or http://www.naturemade.ch
} 


\begin{tabular}{|c|c|c|c|c|c|c|}
\hline Phase & Time & Suppliers & Consumers & $\begin{array}{l}\text { Market } \\
\text { Share }\end{array}$ & Products & $\begin{array}{l}\text { Market Li } \\
\text { beralisation }\end{array}$ \\
\hline Introduction & $\begin{array}{l}\text { Late80ies, } \\
\text { Early 90ies }\end{array}$ & $\begin{array}{l}\text { Private } \\
\text { Persons, } \\
\text { Grassroots, } \\
\text { Early Utility } \\
\text { Pioneers }\end{array}$ & $\begin{array}{l}\text { Technological } \\
\text { Enthusiasts, } \\
\text { Dark Greens }\end{array}$ & $\begin{array}{l}\text { little more } \\
\text { than zero }\end{array}$ & distributed PV & no \\
\hline $\begin{array}{l}\text { Early } \\
\text { Growth }\end{array}$ & Late 90ies & $\begin{array}{l}\text { Mainly } \\
\text { Municipal } \\
\text { Utilities }\end{array}$ & $\begin{array}{l}\text { Early } \\
\text { Adopters, } \\
\text { "Greenback } \\
\text { Greens", } \\
\text { Community- } \\
\text { oriented } \\
\text { customers, } \\
\text { Pioneering } \\
\text { businesses }\end{array}$ & $\begin{array}{l}<1 \% \\
\text { (participation } \\
\text { rate up to } \\
5 \% \text { ) }\end{array}$ & $\begin{array}{l}\mathrm{PV}, \text { some } \\
\text { wind and } \\
\text { small hydro }\end{array}$ & $\begin{array}{l}\text { discussion } \\
\text { starting }\end{array}$ \\
\hline Take-Off & Early 00s & $\begin{array}{l}\text { Municipal } \\
\text { Utilities plus } \\
\text { some Large } \\
\text { Utilities }\end{array}$ & $\begin{array}{l}\text { Early } \\
\text { Majority, } \\
\text { Light Greens, } \\
\text { B2B }\end{array}$ & $3-5 \%$ & $\begin{array}{l}\text { renewable } \\
\text { mix incl. } \\
\text { some hydro; } \\
\text { pure hydro } \\
\text { (mainly for } \\
\text { export) }\end{array}$ & in progress \\
\hline
\end{tabular}

\begin{tabular}{|c|c|c|c|c|c|c|}
\hline $\begin{array}{l}\text { Maturity } \\
\text { (optimistic } \\
\text { scenario) }\end{array}$ & $2005 \mathrm{ff}$. & $\begin{array}{l}\text { Utilities \& } \\
\text { New Entrants }\end{array}$ & Late Majority & $20-30 \%$ & $\begin{array}{l}\text { renewable mix } \\
\text { incl. certified } \\
\text { green hydro }\end{array}$ & completed \\
\hline $\begin{array}{l}\text { Maturity } \\
\text { (pessimistic } \\
\text { scenario) }\end{array}$ & $2005 \mathrm{ff}$. & $\begin{array}{l}\text { Utilities \& } \\
\text { New Entrants }\end{array}$ & as in Take -Off & $\begin{array}{l}\text { stuck at } \\
3-5 \%\end{array}$ & $\begin{array}{l}\text { pure hydro } \\
\text { with low } \\
\text { credibility vs. } \\
\text { high end new } \\
\text { renewables }\end{array}$ & completed \\
\hline
\end{tabular}

Fig. 5. Overview on the phases of green power market development in Switzerland.

well as to low-impact hydropower, i.e. hydropower that meets additional environmental criteria. Both levels include an obligation for the marketer to sell a minimum amount of electricity from new renewables $(2.5 \%$ of the certified green power sales) and low-impact hydropower (another 2.5\%). The scope of certification is focused at two points in the production chain: first at the individual power plant and second at the electricity product, which is offered to the customers.

Green power plants which are certified according to Naturemade star are considered as ecological leaders and have to fulfil additional environmental benefits: The power plant in question has to pass below a certain threshold regarding its life cycle characteristics. ${ }^{19}$ Beyond that global evaluation, eco-leaders have to meet certain local minimum standards. PV-plants have to be installed in the built environment and wind turbines are restricted to certain areas in order to minimise the impact on landscape.

In the case of hydropower, there is a more complex differentiation to be applied: green hydropower plants have to meet a set of basic criteria and have to additionally invest into a fund for environmental improvements in the plant's catchment area (Bratrich

\footnotetext{
${ }^{19}$ Life cycle characteristics are measured following the Ecoindicator 99 methodology with a hierarchist weighing of the individual impact areas. Proposals for a threshold are at $30 \%$ of the value of a modern gas and steam power plant, see Frischknecht and Jungbluth (2000).
}

and Truffer, 2001). ${ }^{20}$ The basic criteria are arranged into five management topics and also five different environmentally relevant areas (Fig. 6).

Plants that do not opt for Naturemade star certification may choose the Naturemade basic label, which allows for differentiation from fossil fuels or nuclear energy sources. ${ }^{21}$ Concerning hydropower, the certification relates to net energy production, i.e. losses and nonrenewable energy input for pumped storage plants are excluded. All certified power plants (star and basic) beyond a capacity of $10 \mathrm{MW}$ are expected to implement an environmental management system (EMS) within a 5 -year period.

The current concept of the Swiss green power label represents the endpoint of a long and difficult negotiation and development process among the different stakeholders. The following paragraph highlights some of the key points in this process.

\footnotetext{
${ }^{20}$ Contribution to the fund is $0.1 \mathrm{Rp}$./kWh produced plus $0.9 \mathrm{Rp}$./ $\mathrm{kWh}$ sold in Switzerland.

${ }^{21}$ There have been concerns among environmental organisations about a potential dominance of Naturemade basic-certified products with little environmental value added. This has been addressed by focussing initial marketing and public education efforts on Naturemade star rather than basic. Also, certified suppliers of both levels have to meet the obligation regarding minimum sales of new renewables.
} 


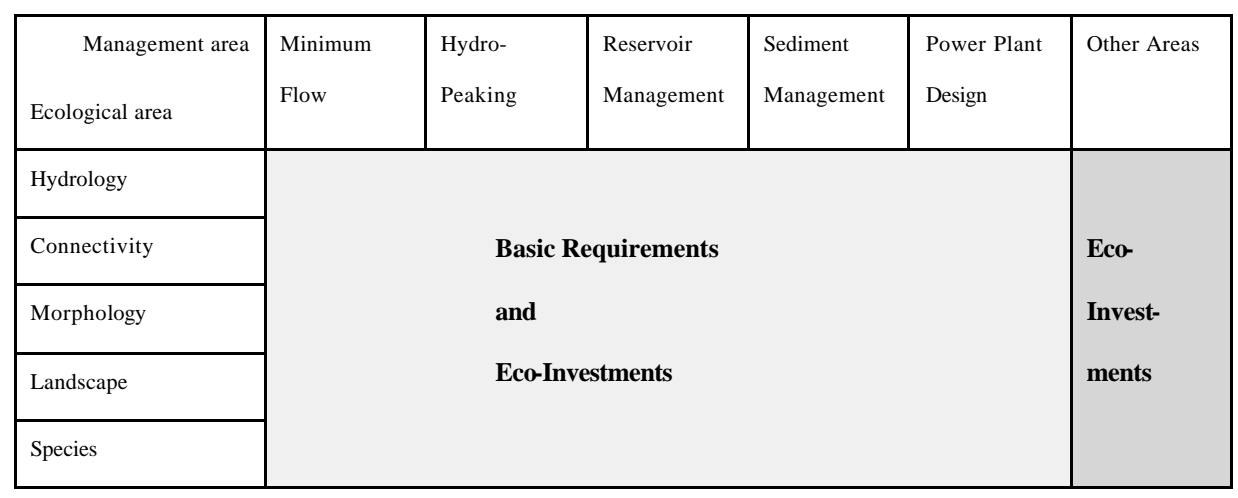

Fig. 6. Structure of "Naturemade star" labelling requirements in the case of hydropower (Source: Bratrich and Truffer, 2001).

\subsection{Overcoming the social dilemma in the case of hydropower}

Electricity generation from hydropower has some ambiguous characteristics. Being renewable, $\mathrm{CO}_{2}$-free and highly energy efficient from a global perspective, it causes quite severe local impacts on aquatic ecosystems and landscape. With now more than $80 \%$ of the available potential being used, hydropower generation in Switzerland quite early had to face rising opposition from environmentalists claiming not to further exploit the resources and to mitigate already existing impacts.

In the 1980s, the conflicts escalated in public protest movements against new dam projects. Finally, the renewal of the Swiss water protection act in 1991backed up by a popular vote-set up more severe requirements for the use of hydropower. While in principle codifying high ecological quality standards, the new act turned out to be a Pyrrhic victory for the environment. Its restrictions intervened in existing water use rights and therefore in fact could not be applied until the concessions expired and had to be renewed. The concessions usually have a long-term validity of 80 years, so in most cases renewals were not due for the next 40 years, which would leave the environmental situation nearly unchanged for decades to come. Moreover, the conflicts between industry and environmentalists hardened. Consequently, the public image of hydropower in Switzerland got worse over time and the ecological problems remained unsolved.

Upcoming market liberalisation led to an increasing cost pressure on electricity suppliers. Marketing low impact hydropower seems to be a promising strategy in order to realise higher prices in the new, green market segment. Credibility of environmental claims is one of the major issues to tackle for electric utilities when entering into the green power market. Environmental organisations, on the other hand, have a highly credible image in the public; at least as far as ecological standards are concerned. In order to push forward

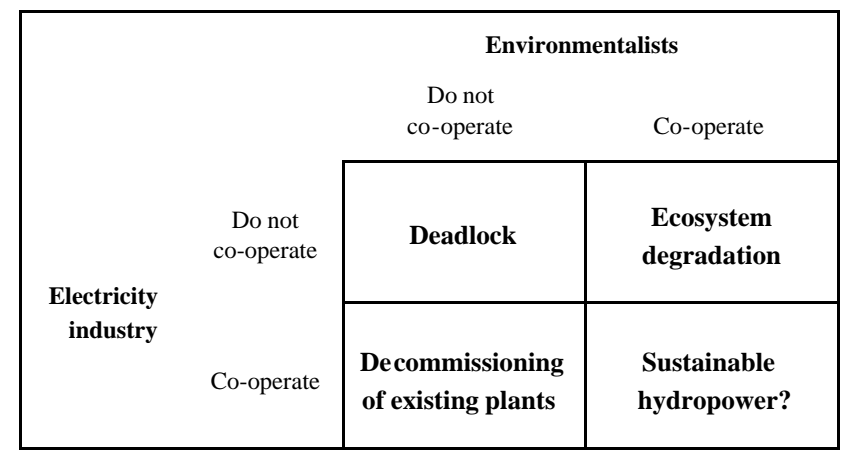

Fig. 7. Eco-standards for hydropower: The dilemma situation in Switzerland.

ecological improvements, they are furthermore interested in green electricity products to be marketed successfully and the know-how of the electricity industry to be mobilised. In this situation, a broadly supported eco-label could be both a powerful, credible marketing tool for electricity suppliers, and a means for the environmental upgrading of certified power plants. Despite the existence of a potential win-win situation, the development of a common labelling standard faced several barriers, which require further analysis.

The decision options of electricity industry actors and environmental organisations can be described according to the ideas of game theory (cf. e.g. Rasmussen, 1989). Fig. 7 gives a qualitative analysis of the pay-offs.

As long as both actors do not cooperate, there is virtually no chance for a common standard and the status quo remains unchanged (“deadlock"). If the environmentalists cooperate, i.e. accept a lower standard while the producers follow the hard line a higher (short to medium term) economic benefit for the industry may result-to the disadvantage of the environment ("ecosystem degradation"). The opposite holds true for environmental organisations not agreeing in a compromise and industry withdrawing. Due to high environmental standards, some power plants could then 
no longer be run economically and investments for ecological improvements could not be amortised ("decommissioning of existing plants").

Bilateral cooperation may pay off for both players, in leading to a common standard for sustainable hydropower. Albeit this situation is pareto-efficient, it will not be achieved as long as both sides strive for a maximisation of individual benefit. Individual calculation in this case results in a preference for non-cooperative behaviour. Such existence of dominant strategies leads to a pareto-inefficient result which from literature is known as the "prisoners' dilemma" (Hohmann and Pies, 1991, p. 609). The deadlock situation may remain stable as long as the interests within each group are relatively homogenous and the players cannot communicate.

In Switzerland, the initiative to overcome this dilemma came from two pioneers, the municipal utility of Zurich (EWZ) and the World Wide Fund for Nature (WWF), respectively. Both agreed that a successful label would be mutually beneficial, but could only be achieved by means of cooperation between the different actors. The utility's rationale was that its successful solar power marketing campaign could not per se be transferred to the controversial issue of hydropower without having credible environmental organisations on board. It also recognised that, as more and more competitors launched products of varying quality, independent certification was crucial for the success of the green power market as a whole. The NGO, on the other side, by introducing additional incentives for utilities, saw the potential to speed up the process of ecological upgrading of hydropower that would have lasted for decades on the basis of the mere water protection act. The initiative was backed by a transdisciplinary research project of the Swiss Federal Institute for Environmental Science and Technology (EAWAG). ${ }^{22}$ This project had the objective to develop scientifically based criteria for sustainable hydropower, but also to transfer this knowledge into real world contexts (Truffer et al., 2001b).

At the beginning of 1998, a working group "green electricity label" was established and the EAWAG project started. In 1999, a consulting company (Kiefer \& Partners AG) was hired by EWZ and WWF to develop a business plan for the label. Scientists from EAWAG engaged in several negotiation meetings with all relevant stakeholders, thus increasing the acceptance of the evaluation procedure. After another year of mediation as well as research concerning the criteria for low impact hydropower, the Association for Environmentally Sound Electricity (VUE) could be founded. The board of VUE consists of a broad set of stakeholders, including representatives of environmental NGOs, consumer associations, solar, wind and biomass

\footnotetext{
${ }^{22}$ http://www.oekostrom.eawag.ch
}

associations, hydropower producers, electric utilities and industrial electricity users.

Some important lessons can be learned from the process. The stakeholder involvement turned out to be essential for the development of commonly accepted standards. Hence, eco-labelling generally has a potential to lead to a win-win situation for all market actors involved: producers and suppliers, consumers and environmental organisations.

Moreover, labelling has the potential to set up a constructive mediation process and to overcome previous conflicting interest positions. The Swiss experience underlines that it is crucial to address the different stakeholders early on and to explicitly integrate the relevant groups in the standard development process. If major interest positions are neglected, there is a danger of either small uptake of the label or even a counterproductive development of alternative and then competing certification schemes as it happened in the German market (Truffer et al., 2001a). In this case, the promotional function of eco-labelling can actually be reversed, by increasing rather than decreasing transaction cost for consumers.

In the Swiss case of green power, not only the procedural design of label development was essential for a cooperative solution, but also the initial constellation of involved actors and the emerging market environment: The exogenous change of market conditions created a strong incentive to overcome some old entrenched conflict lines. A consensus oriented labelling strategy with broad stakeholder involvement, as it was pursued in Switzerland, involves a resource intensive discussion process. Especially, the basic and the final design phase may require a lot of time and money. In the Swiss case, it took 2 years from initial discussions until the actual launch of the labelling scheme. Furthermore, the evaluation criteria as well as the certification procedure have become quite complex, which may become a challenge with regard to the public perception and understanding of the label.

\subsection{European perspectives of eco-labelling}

Given the experiences gained in the Swiss labelling initiative, what lessons can be learned for a label on the European level? As national electricity markets start to converge towards a common European market, eco-labelling for electricity products may play an increasingly international role. Ongoing liberalisation and varying levels of renewable energy supply will likely promote cross-border trading of green electricity. The recent significant rise in the demand for green electricity in the Netherlands, for example, calls for increasing imports from neighbouring countries (Bird, Wüstenhagen and Aabakker, 2002). Moreover, the ambitious aims of the European Union for the support 
of electricity from renewable energy sources pressure for a common definition of green power (European Commission, 2000). The same holds true for the implementation of quota-based support schemes and for tradable "green certificates". ${ }^{23}$ Finally, common definitions are also required in order to harmonise tax exemptions for renewable energy.

There have been European definitions for electricity from renewable energy sources already (European Commission, 2000; RECS, 2000), which may provide some general orientation. Still, with regard to an ecolabel on the European level those definitions fall short as soon as the assessment of ecological impacts of electricity production from renewables gets complex like for instance in the case of biomass or hydropower (Truffer et al., 2001a).

For those reasons, we expect a growing need for a European harmonisation of national green power standards.

A European eco-label for electricity may be designed and set up in different ways (Markard and Truffer, 1999). From the present point of view, a coordination initiative for green power issues seems to be suitable for the implementation of common principles on green power generation, products and certification procedures. This may assure minimum standards and as well allowing for co-existence of different national requirements. Existing labels could jointly come together under a European umbrella and benefit from the services of an international platform. Especially producers or green power providers will have much more easily access to a certified product and can minimise their efforts for labelling.

Currently, an NGO-initiative called EUGENE (European Green Electricity Network), which encompasses about 30 representatives from mostly environmental NGOs, is working towards that direction. ${ }^{24}$ For almost 2 years now, there have been several plenary meetings as well as working groups on the topics of biomass, hydropower, co-generation, additionality, disclosure and principles. This process is challenging due to national particularities and different starting points. ${ }^{25}$

\footnotetext{
${ }^{23}$ Tradable renewable energy certificates (or green certificates) are being discussed in several countries and have actually been introduced e.g. in the Netherlands in connection with quota-based support schemes for renewable energy (or Renewable Portfolio Standards, RPS). The basic idea is that a producer of renewable energy gets a certificate for each MWh of electricity that he generates. The "green benefit" of renewable energy can then be traded separately from the actual MWh. The certificates will then be redeemed as soon as the electricity is actually sold to the end user, and this verifies his compliance with the RPS

${ }^{24}$ http://www.climnet.org/eugene.htm

${ }^{25}$ Experiences from the Scandinavian countries underline the difficulties of negotiating common principles of Green Electricity: NGOs in Sweden and Finland achieved no consensus to apply the Swedish eco-label BraMiljöval also in Finland. Today, BraMiljöval
}

Moreover, achieving a widely accepted standard may require involving an even broader constituency. Hence the complexities faced by the project of introducing a European eco-labelling scheme are considerable. While the EUGENE initiative is definitely instrumental in facilitating the European discussion, it remains to be seen how quickly national standards will converge towards a common European label.

A complementary measure may be the development of a common scheme for electricity information disclosure. ${ }^{26}$ This includes the standardised, consumeroriented declaration of information like fuel mix, price and environmental characteristics of every electricity product in the market. In contrast to an eco-label, electricity disclosure provides objective, disaggregated information rather than making a value judgement on the product. A general disclosure standard may raise public awareness about electricity generation issues, and could consequently become an important tool for consumer protection and market transparency (Holt, 1997; Nogee et al., 1999; Markard, 2001).

\section{Conclusions and outlook}

This paper has given an overview on the development and current trends on the Swiss green power market and the development of an encompassing green power labelling scheme. It could be seen that while there are a number of similarities with other countries, the Swiss case shows some particular aspects:

- The Swiss electricity market is being liberalised at a much lower pace than many of the EU countries. This provides the suppliers with more time to experiment with green power products while still being protected from new competitors, at least in the retail market. Given the experience from other countries like Germany, this might significantly increase customer loyalty towards the Swiss suppliers and make it difficult for new suppliers to successfully enter the green power market when it is finally liberalised.

- Looking at the relatively high response rates of the very expensive solar power offerings of many Swiss utilities, it can be estimated that willingness to pay (WTP) for green electricity is higher in Switzerland than in other countries, which might partly be due to the high income of average Swiss households.

(footnote continued)

principles are applied in Sweden and Norway whereas Finland has a different eco-label (Luukkanen, J., Finland Futures Research Centre, Turku, e-mail communication, November 11, 2001).

${ }^{26}$ An early example of a power disclosure standard is the Californian Power Content Label (see http://www.energy.ca.gov/consumer/power_content_label.html), which had been introduced in 1998 (Wüstenhagen, 2000). 


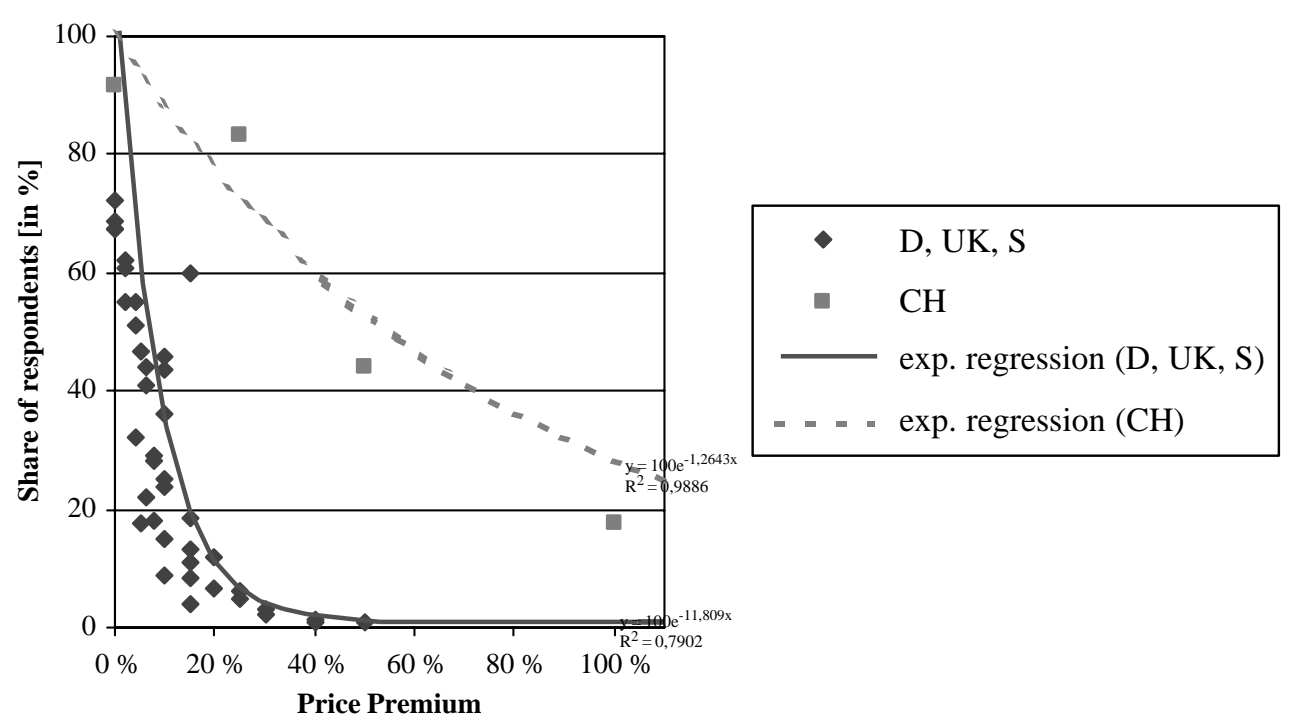

Fig. 8. Stated willingness-to-pay for green electricity in Germany, UK, Sweden and Switzerland (household customers). (Source: Wüstenhagen, 2000, based on data of various market research reports published 1996-2000.)

Another indication of this are results of market research studies from the city of Zurich, which show much higher WTP than customers in the UK or German markets (cf. Fig. 8). ${ }^{27}$ However, this has to be further verified due to methodological limitations of this sort of quantitative market research and the fact that consumers' preferences (and hence WTP) will co-evolve with new offerings on the liberalised market.

- The high share of hydropower clearly differentiates Switzerland from most of the central European electricity markets. Unlike in coal-based systems like Germany, the UK or many states of the US, renewable energy or low $\mathrm{CO}_{2}$ emissions alone are not a unique selling proposition (USP) for green power in Switzerland, with its hydro-nuclear electricity supply system. This has to be taken into account by the marketers in their product design as well as by the labelling organisation in specifying the criteria for green power certification. However, it might also include the opportunity for marketers to provide a product range that includes both low-cost, nuclearfree electricity (Naturemade basic-certified) and higher-value products with more new renewables and low impact hydropower (Naturemade star-certified), and hence address the different needs of consumers in the eco-niche and beyond. These considerations may also be relevant for other countries with a high share of hydropower, e.g. Norway, Sweden and Austria.

\footnotetext{
${ }^{27}$ The percentages on the $y$-axis refer to all respondents, not only to those who have stated a willingness to pay more for green electricity. The $y$-intercept of the curves has been fixed at 100\% (cf. Farhar, 1999 for a similar analysis of US market research).
}

- The mediation and learning effects of a broadly accepted label are not only useful to reach consensus on this particular issue. Moreover, as the various interest groups realise the benefit of common action and discussions, positive perception for future cooperation can be a consequence. Therefore, spillover effects far beyond the label development process are possible, as for example product designers from the electric utility industry can benefit from the environmental knowledge of NGO experts.

Finally, regarding future research, the interaction between eco-labelling and other policy instruments to promote renewable energy deserves further attention. Depending on the regulatory environment, green power marketing and labelling may play a key role (as in Switzerland) or its role may be rather marginal (as in Germany) in supporting the development of renewable energy. Research should aim at identifying preconditions for synergies, but also analyse situations with negative interference of different policy instruments. An obvious issue to address is the interface between green electricity labelling and tradable green certificates. Both systems need to define "renewables". As a consequence, the value judgements that were at the basis of the Swiss eco-labelling process will also be present in the definition of a certificate standard. ${ }^{28}$ If properly conceived, green certificates can be used by a green power retail marketer to demonstrate the origin of the product he offers. Furthermore, tradable green certificates could also form the basis of a mandatory disclosure standard. A more

\footnotetext{
${ }^{28} \mathrm{~A}$ striking example is the European discussion on hydropower, which oscillates between excluding old vs. new or small vs. large power plants rather than embracing the rational, scientifically based approach that was taken in the Swiss labelling scheme.
} 
integrated approach to these information-enhancing instruments would considerably facilitate the choice of customers. This would ultimately increase the effectiveness of all these instruments to achieve their set goal namely promoting environmentally benign electricity.

\section{Acknowledgements}

The authors wish to thank Atle Midttun, Anne Louise Koefoed, Jyrki Luukkanen, and Niels Meyer for their valuable comments on previous drafts of this paper.

\section{References}

BfE, 2001a. Schweizerische Gesamtenergiestatistik 2000, Bundesamt für Energie, Bern. http://www.energie-schweiz.ch/bfe/de/statistik/

BfE, 2001b. Schweizerische Elektrizitätsstatistik 2000, Bundesamt für Energie, Bern. http://www.energie-schweiz.ch/imperia/md/content/ statistikperspektiven/elektrizittsstatistik/1.pdf

BfE, 2001c. Schweizerische Statistik der erneuerbaren Energien 2000, Bundesamt für Energie, Bern. http://www.energie-schweiz.ch/imperia/md/content/teilstatistiken/6.pdf

Bird, L., Wüstenhagen, R., Aabakker, J., 2002. Green Power Marketing Abroad: Recent Experience and Trends. National Renewable Energy Laboratory, NREL/TP-620-32155, Golden Co, May 2002 (http://www.nrel.gov/docs/fy02osti/32155.pdf).

Brandes, C., 2001. One label-two qualities: Naturemade!, In: Wüstenhagen, R., Giger, N. (Eds.), Proceedings of the First European Conference on Green Power Marketing, St. Moritz, 29/ 30 June 2001.

Bratrich, C., Truffer, B., 2001. Green Electricity Certification for Hydropower Plants. Concepts, criteria and procedures. Ökostrom Publikationsreihe, Band 7, EAWAG, Kastnanienbaum (www.hydropower.ch), $110 \mathrm{p}$.

Elektrizitätsmarktgesetz, 2000. Elektrizitätsmarktgesetz (Swiss Electricity Market Act; EMG) vom 15. Dezember 2000. http:// www.admin.ch/ch/d/ff/2000/6189.pdf

European Commission, 2000. Amended proposal for a Directive of the European Parliament and of the Council on the promotion of electricity from renewable energy sources in the international electricity market. COM(2000) 884, Brussels.

Farhar, B.C., 1999. Willingness to Pay for Electricity from Renewable Resources: a Review of Utility Market Research. National Renewable Energy Laboratory, NREL/TP.550.26148, Golden, CO, July 1999.

Frischknecht, R., Jungbluth, N., 2000. Globale Umweltkriterien für Ökostrom. ESU-services, Zürich.

GfS-Forschungsinstitut der Schweizerischen Gesellschaft für Praktische Sozialforschung, 2000. VOX-Analyse $\mathrm{N}^{\circ}$ 71, Zürich. (Abstract: http://www.polittrends.ch/abstimmungen/abstimmungsanalysen/vox-analysen/002409d.html\#1)

Giger, N., 1999. Die EWZ-Solarstrombörse-Das Originalmodell des Elektrizitätswerkes der Stadt Zürich. Konzept und Erfahrung nach zwei Jahren Kundennachfrage, Paper presented at the conference "Grüner Strom"-Die Macht der Konsumenten, Messe erneuerbare Energien 1999 at Böblingen, 27.02.1999.

Hohmann, K., Pies, I., 1991. Wirtschaftsethik und Gefangenendilemma. In: Wirtschaftswissenschaftliches Studium (WiSt), Heft 12, Marburg.

Holt, E., 1997. Disclosure and Certification: Truth and Labeling for Electric Power. REPP Issue Brief No. 5. Renewable Energy Policy Project, College Park, MD.
Holt, E., Wiser, R., 1999. Understanding Consumer Demand for Green Power, Paper Prepared for the National Wind Coordinating Committee, Final Draft, Harpswell, MA/Berkeley, CA, May 1999.

Jegen, M., Wüstenhagen, R., 2001. Modernise it, sustainabilise it! Swiss energy policy on the eve of electricity market liberalization. Energy Policy 29, 45-54.

Kiefer, B., 2000. Creating an eco-label for electricity in Switzerlandthe art of mediating between diverging interests. In: Scholz, R. et al. (Eds.), Transdisciplinarity: Joint Problem-Solving among Science, Technology and Society, Proceedings of the International Transdisciplinary 2000 Conference, Workbook I, Zurich.

Linder Kommunikation, A.G., (Ed.), 1999. Erfolgsrezepte für das Solarstrom-Marketing. Untersuchung im Auftrag des Bundesamtes für Energiewirtschaft. Linder Kommunikation AG und Ipso Sozial- Marketing- und Personalforschung, Zürich.

Markard, J., 2001. Fokusgruppen-Erhebung zur Kennzeichnung von Elektrizität - Informationsbedürfnisse von Konsumentinnen und Konsumenten. Swiss Federal Office of Energy (BFE), Bern.

Markard, J., Truffer, B., 1999. Der lange Weg zu einem Euro-Label für Strom. Energiewirtschaftliche Tagesfragen 49/11, 724-729.

Naturemade, 2001. Liste der Ökostrom-Zertifizierungen, Stand 10.12.2001, Zurich.

Nogee, A., Clemmer, S., Paulos, B., Haddad, B., 1999. Powerful Solutions. 7 Ways to Switch America to Renewable Electricity. Union of Concerned Scientists, Cambridge/MA.

Nordmann, T., 1997. Success Stories of Photovoltaic Financing in Europe, Paper presented at the 14th European Photovoltaic Conference and Exhibition, Barcelona, 30 June-4 July 1997.

Rasmusen, E., 1989. Games and Information: An Introduction to game theory. Oxford, Blackwell.

Roper Starch Worldwide, 2001. Roper Green Gauge 2000-Rising Concerns. In: NREL (Ed.), Proceedings of the Sixth National Green Power Marketing Conference, Portland/Oregon, August 1, 2001.

RECS, 2000. RECS Basic Commitment-Version 4. Renewable Energy Certificate System (RECS), Rotterdam.

Rogers, E.M., 1995. Diffusions of innovations, 4th Edition, New York, etc. free press.

Spielhofer, J., 2000. Wie wird mit Windstrom eine Marke veredelt? In: IIR Deutschland GmbH (Ed.), Strategisches Marketing im Schweizer Energiemarkt, Proceedings, Zürich, 22/23 March 2000.

Truffer, B., 1998. Market demand for green power products, in: The Greening of Industry Network: Partnership and Leadership: Building Alliances for a Sustainable Future, conference proceedings, Rome, November 15-18, 1998.

Truffer, B., Markard, J., Wüstenhagen, R., 2001. Eco-labeling of electricity - strategies and tradeoffs in the definition of environmental standards. Energy Policy 29 (11), 885-897.

Truffer, B., Bratrich, C., Markard, J., Wehrli, B., 2001. Ökostrom: the social construction of green electricity standards in Switzerland. In: Thompson Klein, J., et al. (Ed.), Transdisciplinarity: Joint Problem Solving among Sicence, Technology and Society. An Effective Way for Managing Complexity. Birkhäuser, Basel, pp. 153-158.

Villiger, A., Wüstenhagen, R., Meyer, A., 2000. Jenseits der ÖkoNische, Basel/Boston/Berlin. Burkhäuser.

Wüstenhagen, R., 1998. Green electricity in Switzerland. A mere econiche or the first step towards a sustainable energy market at large? In: International Association for Energy Economics (Eds.), Energy Markets: What's New? Berlin, pp. 143-151. (also available online at http://www.iwoe.unisg.ch)

Wüstenhagen, R., 2000. Ökostrom-von der Nische zum Massenmarkt, (Green Electricity- from Niche to Mass Markets) Entwicklungsperspektiven und Marketingstrategien für eine zukunftsfähige Elektrizitätsbranche. Vdf Hochschulverlag, Zürich. 